\title{
Efficacy of rabies vaccines in dogs and cats and protection in a mouse model against European bat lyssavirus type 2
}

Tiina Nokireki ${ }^{*}$, Miia Jakava-Viljanen ${ }^{1}$, Anna-Maija Virtala² and Liisa Sihvonen ${ }^{1,2}$

\begin{abstract}
Background: Rabies is preventable by pre- and/or post-exposure prophylaxis consisting of series of rabies vaccinations and in some cases the use of immunoglobulins. The success of vaccination can be estimated either by measuring virus neutralising antibodies or by challenge experiment. Vaccines based on rabies virus offer cross-protection against other lyssaviruses closely related to rabies virus. The aim was to assess the success of rabies vaccination measured by the antibody response in dogs $(n=10,071)$ and cats $(n=722)$, as well as to investigate the factors influencing the response to vaccination when animals failed to reach a rabies antibody titre of $\geq 0.5 \mathrm{IU} / \mathrm{ml}$. Another aim was to assess the level of protection afforded by a commercial veterinary rabies vaccine against intracerebral challenge in mice with European bat lyssavirus type 2 (EBLV-2) and classical rabies virus (RABV), and to compare this with the protection offered by a vaccine for humans.

Results: A significantly higher proportion of dogs (10.7\%, 95\% confidence interval Cl 10.1-11.3) than cats (3.5\%; $95 \%$ $\mathrm{Cl}$ 2.3-5.0) had a vaccination antibody titre of $<0.5 \mathrm{IU} / \mathrm{ml}$. In dogs, vaccination with certain vaccines, vaccination over 6 months prior the time of antibody determination and vaccination of dogs with a size of $>60 \mathrm{~cm}$ or larger resulted in a higher risk of failing to reach an antibody level of at least $0.5 \mathrm{IU} / \mathrm{ml}$. When challenged with EBLV-2 and RABV, 80 and $100 \%$ of mice vaccinated with the veterinary rabies vaccine survived, respectively. When mice were vaccinated with the human rabies vaccine and challenged with EBLV-2, 75-80\% survived, depending on the booster. All vaccinated mice developed sufficient to high titres of virus-neutralising antibodies (VNA) against RABV 21-22 days post-vaccination, ranging from 0.5 to $128 \mathrm{IU} / \mathrm{ml}$. However, there was significant difference between antibody titres after vaccinating once in comparison to vaccinating twice $(P<0.05)$.

Conclusions: There was a significant difference between dogs and cats in their ability to reach a post vaccination antibody titre of $\geq 0.5 \mathrm{IU} / \mathrm{ml}$. Mice vaccinated with RABV-based rabies vaccines were partly cross-protected against EBLV-2, but there was no clear correlation between VNA titres and cross-protection against EBLV-2. Measurement of the RABV VNA titre can only be seen as a partial tool to estimate the cross-protection against other lyssaviruses. Booster vaccination is recommended for dogs and cats if exposed to infected bats.
\end{abstract}

Keywords: Antibody, EBLV-2, Lyssavirus, Protection, Rabies, Vaccination

\section{Background}

Rabies is a fatal encephalomyelitis caused by lyssaviruses. Rabies virus (RABV) causes about $99 \%$ of all rabies cases in humans, mostly in Asia and Africa. Even though the

\footnotetext{
*Correspondence: tiina.nokireki@evira.fi

1 Finnish Food Safety Authority Evira, Mustialankatu 3, 00790 Helsinki, Finland

Full list of author information is available at the end of the article
}

case fatality is almost $100 \%$, the disease can be prevented by pre-exposure vaccination and by post-exposure treatment shortly after exposure. Pre-exposure vaccination can prevent the disease, but booster vaccination upon exposure is required to ensure that the immune system responds optimally [1]. Thirteen other lyssavirus species have been accepted by the International Committee on Taxonomy of Viruses, and two additional species have 
been identified. Phylogenetic analysis and the virushost relationship suggest that all 16 currently identified species of lyssaviruses can be divided into phylogroups. Phylogroup I comprises RABV, Duvenhage virus, European bat lyssavirus types 1 and 2 (EBLV-2), Australian bat lyssavirus, Aravan virus, Khujand virus, Irkut virus and Bokeloh bat lyssavirus, whereas Lagos bat virus, Mokola virus and Shimoni bat virus form phylogroup II $[2,3]$. West Caucasian bat virus, Ikoma lyssavirus and Lleida bat lyssavirus may be representatives of possible new phylogroups [4-6]. Gannoruwa bat lyssavirus probably belongs to phylogroup I [7].

Human infections usually result from the bite of a rabid dog infected with RABV [1]. However, in a small number of cases, the infection results from contact with bats [8]. Two confirmed human cases caused by European bat lyssavirus type 2 (EBLV-2), one in Finland in 1985 [9, 10 ] and one in the UK in 2002 [11] have been reported. EBLV-2 is known to associate with two closely related Myotis bat species, Daubenton's (Myotis daubentonii) and pond bats (M. dascyneme). EBLV-2 has sporadically been isolated from Daubenton's bats in the Netherlands [12], Switzerland [13], the UK [14], Finland [15, 16], Germany [17], Denmark [18] and Norway [19]. Finland was declared a rabies-free country by the OIE in 1991. Nevertheless, rabies can remain a residual risk to public health due to the natural circulation of EBLV-2 $[15,16]$. Spillovers from chiropters to carnivores are not unusual, and at least two spillovers of RABV from bats to carnivore hosts have occurred, which have succeeded in being maintained through time $[20,21]$. No spillover infections to other mammals than humans have been detected for EBLV-2. In experimental infections, EBLV-2 has been shown to cause fatal disease in foxes [22], sheep [23] and mice $[24,25]$. European bat lyssavirus type 1 (EBLV-1), however, has been detected in natural infections of stone martens (Martes foina) [26], sheep [27] and domestic cats [28].

The assessment of rabies vaccine efficacy $[1,29,30]$ is usually undertaken by immunisation and virus challenge using laboratory animals (potency test). The efficacy of vaccination can be indirectly assessed by measuring antibodies from serum. Cellular immunity, however, is also important in clearing a virus infection [31]. Virus-neutralising antibody assays are used to verify that an immune response has occurred. An internationally accepted threshold titre of $0.5 \mathrm{IU} / \mathrm{ml}$ has been adopted [1]. However, it has been shown that vaccinated animals with low antibody levels have survived RABV challenge, indicating that other immune mechanisms also protect against rabies infection. On the other hand, according to Aubert [32], the presence of detectable neutralising antibodies against rabies at the time of challenge does not indicate protection for all animals. Nevertheless, animals with neutralising antibodies at the time of challenge are significantly better protected against RABV than those without detectable virus neutralizing antibodies (VNA) [32, 33]. Information on the protection and cross-protection efficacy of rabies vaccines against all other lyssaviruses under field conditions is still limited. Protection is inversely related to the genetic distance of the lyssavirus from RABV [34, 35].

The type of vaccine used, number of vaccinations, interval between vaccination and blood sampling, age at vaccination, sex, reproductive status, size and breed can all influence the antibody response of animals vaccinated against rabies [36-39]. In post-vaccination serological studies, the percentage of animals with inadequate titres has been $3.1-8.1 \%$ for dogs $[36,38,40]$ and $2.85 \%$ for cats [36]. As many as 53\% (95\% CI 41-65\%) of imported rescue dogs from Eastern Europe have been found to have inadequate titres after rabies vaccination [41].

Pre-exposure vaccination is recommended for people potentially at risk of rabies, such as veterinarians, laboratory workers and bat handlers. People who work with rabies viruses in laboratories or vaccination production facilities should have VNA tested every 6 months [1]. According to $\mathrm{WHO}$ recommendations, $0.5 \mathrm{IU} / \mathrm{ml}$ is a sufficient antibody level, considered to be proof of an adequate vaccination response, and a booster vaccination is recommended for levels lower than this. A series of booster vaccinations is also required after exposure to lyssavirus [1]. The same threshold titre is applied in dogs and cats to confirm a satisfactory response to vaccination prior to international travel. All vaccines currently available are based on RABV. According to studies conducted to investigate the cross-neutralisation of sera and crossprotection in a mouse model against different lyssaviruses, they offer variable cross-protection against other lyssaviruses [34, 35, 42-46]. However, there are no official recommendations by WHO concerning whether the current procedure of pre-and post-exposure treatment would need to be modified for people who are exposed to other lyssaviruses than RABV.

The aim of this study was to assess the success of rabies vaccination measured by the antibody response in dogs and cats, as well as to study the factors influencing the inability of animals to produce a sufficient antibody response. In addition, the aim was to assess how well an RABV-based rabies vaccine, selected based on the ability to induce an antibody response in dogs and cats, affords protection in a mouse model against intracerebral challenge with EBLV-2 isolated from a Finnish bat (FI-EBLV-2), as well as against challenge with RABV isolated from a Finnish raccoon dog (FIRD-RABV). We also examined the protection offered by a rabies vaccine 
for humans and the correlation between VNA titres and cross-protection against EBLV-2 in mice.

\section{Methods \\ Viruses}

A Finnish EBLV-2 (FI-EBLV-2) isolate obtained from a Daubenton's bat in 2009 (GenBank Accession Number JX129233) was used as the challenge virus. The original bat brain suspension was intracerebrally inoculated into eight newborn mice (ScaNmri suckling mice) with each mouse receiving $20 \mu \mathrm{l}$ of the suspension. The brain suspension from these eight newborn mice was subsequently inoculated into 4-week-old mice to amplify the virus and obtain the required quantity of virus stock to be used as the challenge virus in this study. RABV isolated from a Finnish raccoon dog (FIRD-RABV) (R1470/88) in 1988 was also used in this study. The original archived brain passage had been kept at $-70{ }^{\circ} \mathrm{C}$ since 1990 , and for this challenge study it was grown in the brain of 4-week-old mice to amplify the virus and obtain the required quantity of virus stock.

\section{Vaccination and virus challenge of mice}

Three- to four-week-old NMRI mice (Harlan, NL; $\mathrm{n}=20$ per challenge virus and $n=5$ vaccine only) were vaccinated intra-peritoneally with $0.1 \mathrm{ml}$ of vaccine diluted 1:10 in physiological saline solution with a $16-\mathrm{mm}$ needle. When the human vaccine (Rabies-Imovax ${ }^{\circledR}$; SanofiPasteur MSD, France, batch G1391-4) was used, the mice were vaccinated either once (group a) or twice (group b) with a 2-week interval between the initial and the booster vaccination. When the animal vaccine (Rabisin ${ }^{\circledR}$ vet; Merial, France, batch L374051) was used, the mice were vaccinated once. Vaccines were purchased from Helsinki University Pharmacy. The protocol was modified from the European Pharmacopoiea protocol [29]: the minimum lethal dose $\left(\mathrm{MLD}_{50}\right)$ for the intra-cranial challenge was determined according to protocol of European Pharmacopoeia [29] and $50 \mathrm{MLD}_{50}$ was used. The mice were challenged intra-cranially with $30 \mu \mathrm{l}$ of virus suspension according to the procedure described by WHO [47] 28 days after vaccination. The mice were anesthetized by inhalation anaesthesia using isoflurane, and they were given $0.05-0.1 \mathrm{mg} / \mathrm{kg}$ buprenorphine hydrochloride subcutaneously at the time of intra-cranial challenge. The back titration of five mice per group was set up with 50 $\mathrm{MLD}_{50}, 5 \mathrm{MLD}_{50}$ and $0.5 \mathrm{MLD}_{50}$ of each virus. Five mice per vaccine were not challenged. The mice were monitored twice per day for any clinical signs of rabies, and to minimize suffering they were killed when signs of rabies infection were obvious (weight loss, behavioural changes, neurological signs and paralysis) or when the observation period of 6 weeks had ended.
Serum was collected from the vaccinated mice prior to the challenge 21 or 22 days after the vaccination. The serum was collected from the lateral tail vein by appropriately trained personnel. The tail was first warmed and blood was collected with a 23 -gauge needle. The target volume was $100 \mu \mathrm{l}$. At the end of the trial, the mice were euthanized either by the time they were showing clinical signs or after the monitoring period. To confirm the presence of rabies infection, the brains of the mice were collected and a fluorescent antibody test (FAT) [30] was performed on the brain. Smears prepared from a sample of brain tissue were fixed in high-grade cold acetone, air dried and then stained with specific conjugate (FITC Anti-Rabies Monoclonal Globulin, Fujirebio Diagnostics and Rabies Antinucleocapsid conjugate, Bio-Rad). FAT slides were then examined for specific fluorescence using a fluorescence microscope. The seroconversion of the vaccinated mice was analysed using the rapid fluorescent focus inhibition test RFFIT [30]. Five microlitres of sample was diluted 1:10. Serial dilutions of test sera were mixed with the challenge virus (CVS-11, ATCC VR-959) preparation and BHK-21 cells. Samples were fixed and stained with specific conjugate (FITC Anti-Rabies Monoclonal Globulin, Fujirebio Diagnostics). Residual virus was detected using a standard fluorescence microscope. The serum neutralisation end-point titre was defined as the dilution factor of the highest serum dilution at which $50 \%$ of the observed microscopic fields contained one or more infected cells. OIE/WHO human reference serum was used to convert the end point titre into $\mathrm{IU} / \mathrm{ml}$.

\section{Serological analysis of dogs and cats}

The antibody responses of dogs and cats were determined using the FAVN test [48]. This test involves the neutralisation of a constant amount of rabies virus CVS11 strain adapted to cell culture before inoculating cells susceptible to rabies virus (BHK-21 C13). The serum titre was the dilution at which $100 \%$ of the virus was neutralised in $50 \%$ of the wells. This titre was expressed in IU/ $\mathrm{ml}$ by comparing it with the neutralising dilution of OIE serum of dog origin under the same test conditions.

\section{Selection of dog and cat samples}

This was a case-control study with a duration of 5 years. During 2009-2013, 10,793 serum samples from dogs $(\mathrm{n}=10071)$ and cats $(\mathrm{n}=722)$ were sent to the Finnish Food Safety Authority Evira for post-vaccination efficacy tests. Of these samples, 1055 dogs that had an antibody titre of $<0.5 \mathrm{IU} / \mathrm{ml}$ and for which submission data were available comprised the case group for dogs. An approximately similar number of dogs with submission data that had an antibody titre of $\geq 0.5 \mathrm{IU} / \mathrm{ml}$ were randomly assigned to the control group $(\mathrm{n}=1626)$. In 
cats, only 25 had an antibody titre of $<0.5 \mathrm{IU} / \mathrm{ml}$ (cases), and a much larger number of cats that had antibody titre of $\geq 0.5 \mathrm{IU} / \mathrm{ml}$ were randomly assigned to the control group $(\mathrm{n}=241)$. Submission forms for these samples were evaluated. Three inactivated rabies vaccines were used for dogs and cats in Finland during 2009-2013: Wistar-G52 strain vaccine, BHK-21cell vaccine with Pasteur RIV strain and Flury LEP strain vaccine.

\section{Statistical analysis}

The $95 \%$ confidence intervals (CI) for valid percentages (excluding missing values) were calculated with Jeffrey's method [49] using EpiTools [50]. Statistical analyses were performed using the statistical software SPSS 22.0 (IBM SPSS Statistical Package version 22, USA). The outcome variable was failure to reach the required antibody level ( 0 for antibody level $\geq 0.5 \mathrm{IU} / \mathrm{ml}$, denoting the ability to reach the required antibody level, and 1 for $<0.5 \mathrm{IU} / \mathrm{ml}$, denoting failure). Independent variables collated in the dataset were the vaccine used, age at vaccination, breed and size (only for dogs), gender, the number of vaccinations and the time from vaccination to sampling. Dogs were categorised into five different breed size groups based on their height $(<30 \mathrm{~cm}, 30-45 \mathrm{~cm}$, $46-60 \mathrm{~cm},>60 \mathrm{~cm}$ and unknown). Furthermore, 277 different dog breeds were originally categorized into 10 groups by the Fédération Cynologique Internationale. Animals were divided into two age groups: up to 1 year and over 1 year old. Based on the time interval between vaccination and sampling, three groups were created: sampling less than 3 months after vaccination, 3-6 months after vaccination and more than 6 months after vaccination. First, Fisher's exact test and crude logistic regression analyses were performed to examine the pairwise associations between the outcome and each independent variable separately. Variables with $\mathrm{P} \leq 0.2$ were included in the multivariable logistic regression analysis, with separate models for cats and dogs, and variables with Wald's $\mathrm{P}<0.05$ were included in the final model. Correlations between independent variables were calculated with the Phi test (no important ones were found). A causal diagram was used to assess potential confounders; their impacts on the other variables in the model were verified, but none needed to be included in the models. Pairwise interactions were assessed. Since a significant interaction was found in dogs between the vaccine used and the age of the dog, two separate models were created: one for dogs up to 1 year old and another for older dogs. Additionally, for younger dogs, the time interval between vaccination and sampling was categorized into two groups: up to or more than 6 months. The goodness of fit of the final model was assessed with the Omnibus test, Nagelkerke's $R^{2}$ and the Hosmer and
Lemeshow test, and by calculating the area under the curve (AUC).

\section{Results}

Results of the vaccine potency test

When challenged with FIRD-RABV, all of the vaccinated mice survived. When challenged with FI-EBLV-2, 80\% of the vaccinated mice survived after vaccination with the veterinary vaccine. When mice were vaccinated with the human vaccine, $75-80 \%$ of the mice survived, depending on the booster (Table 1). All vaccinated mice developed sufficient to high VNA titres against RABV, ranging from 0.5 to $128 \mathrm{IU} / \mathrm{ml}$. The signs of rabies appeared 7-8 days post-infection with EBLV-2 and 6-7 days post-infection with RABV. Mice that succumbed after challenge with FI-EBLV-2 virus had a VNA titre of 2-64 IU/ml against RABV (individual results not shown). There were no statistically significant differences between the VNA titres of the mice that survived the challenge in comparison to those that succumbed after the challenge with EBLV-2 (Fig. 1). Mice vaccinated twice with Rabies-Imovax ${ }^{\circledR}$ or once with Rabisin ${ }^{\circledR}$ vet had significantly higher antibody titres than those vaccinated once with Rabies-Imovax ${ }^{\circledR}$ $(\mathrm{P}<0.05)$ (Fig. 2).

\section{Results of the serological analysis of vaccinated dogs and cats}

Of the 10,071 dog samples analysed during 2009-2013, 1073 (10.7\%; 95\% confidence interval CI 10.1-11.3) had

Table 1 Rabies vaccination protection following an intracranial challenge in mice

\begin{tabular}{|c|c|c|c|}
\hline & \multirow[t]{2}{*}{$\begin{array}{l}\text { Total number } \\
\text { of mice }\end{array}$} & \multicolumn{2}{|c|}{$\begin{array}{l}\text { Survival after challenge } \\
\text { with }\end{array}$} \\
\hline & & $\begin{array}{l}\text { FIRD-RABV } \\
\mathrm{n}(\%)\end{array}$ & $\begin{array}{l}\text { FI-EBLV-2 } \\
\text { n (\%) }\end{array}$ \\
\hline $\begin{array}{l}\text { Rabies Imovax, vac- } \\
\text { cinated twice }\end{array}$ & 20 & $20(100)$ & $16(80)$ \\
\hline P value $^{1}$ & & 0.000 & 0.002 \\
\hline $\begin{array}{l}\text { Rabies Imovax, vac- } \\
\text { cinated once }\end{array}$ & 20 & ND & $15(75)$ \\
\hline P value $^{1}$ & & & 0.005 \\
\hline Virus control $50 \mathrm{MLD}_{50}$ & 5 & $0(0)$ & $0(0)$ \\
\hline Virus control 5 MLD $_{50}$ & 5 & $2(40)$ & $2(40)$ \\
\hline Virus control 0.5 MLD $_{50}$ & 5 & $4(80)$ & $4(80)$ \\
\hline $\begin{array}{l}\text { Rabisin, vaccinated } \\
\text { once }\end{array}$ & 20 & $20(100)$ & $16(80)$ \\
\hline P value $^{1}$ & & & 0.002 \\
\hline Virus control $50 \mathrm{MLD}_{50}$ & 5 & $0(0)$ & $0(0)$ \\
\hline Virus control 5 MLD $_{50}$ & 5 & $2(40)$ & $2(40)$ \\
\hline Virus control $0.5 \mathrm{MLD}_{50}$ & 5 & $3(60)$ & $4(80)$ \\
\hline
\end{tabular}

1 P value derived using Fisher's exact test for the number of vaccinated and challenged mice that survived relative to the total and compared with the 50 $\mathrm{MLD}_{50}$ virus control mice 


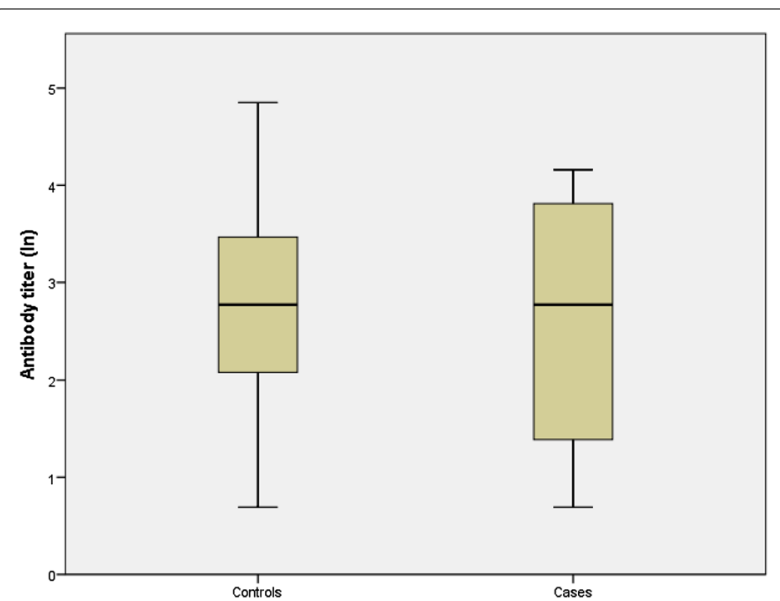

Fig. 1 Comparison of VNA titers (In) of the mice that survived the challenge (controls) and of the mice that succumbed after the challenge with EBLV-2 (cases). The interquartile range is the difference between the 75th and 25th percentiles and corresponds to the length of the box. The lines in the boxes represent the medians, the whiskers represent the minimum and maximum, unless there are values more than 1.5 times the interquartile range above 75 th percentile, in which case it is the third quartile plus 1.5 times the interquartile range

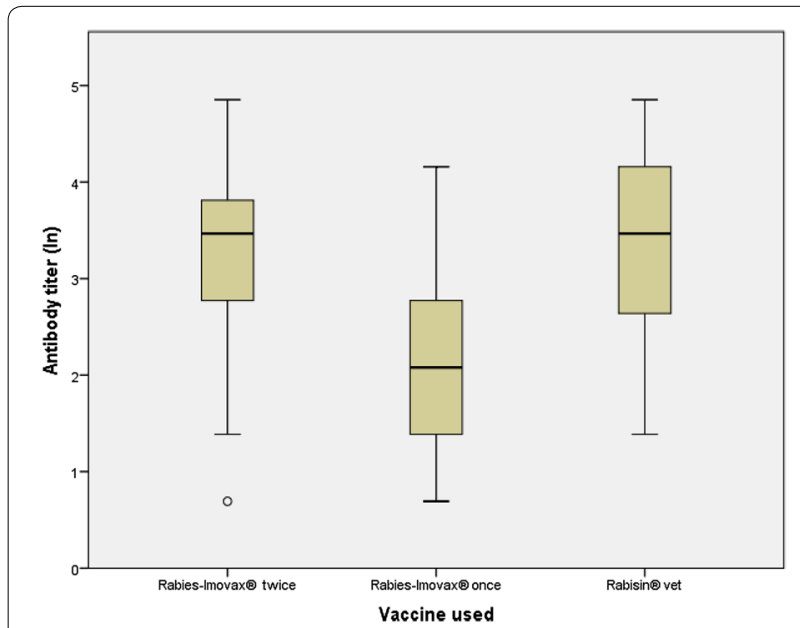

Fig. 2 Comparison of VNA titers (In) in three groups of mice vaccinated with different vaccines or vaccination schemes. The interquartile range is the difference between the 75th and 25th percentiles and corresponds to the length of the box. The lines in the boxes represent the medians, the whiskers represent the minimum and maximum, unless there are values more than 1.5 times the interquartile range above 75 th percentile, in which case it is the third quartile plus 1.5 times the interquartile range. Circles represent outliers that are $>2$ box lengths below the 25 th percentile

a VNA titre of $<0.5 \mathrm{IU} / \mathrm{ml}$. Of the 722 cats analysed, only $25(3.5 \%$; 95\% CI 2.3-5.0) had a VNA titre of $<0.5 \mathrm{IU} / \mathrm{ml}$.
Risk factors for failure to produce sufficient antibody levels in dogs and cats

Descriptive data for the dogs and cats in the case-control study are provided in Tables 2 and 3. Younger dogs were associated with lower antibody titres $(\mathrm{P}<0.05$, data not shown). Since there was a significant interaction between the variables dog age and the vaccine used, two multivariable logistic regression models for dogs were constructed: one for dogs up to 1 year old and another for older dogs. For younger dogs, the Flury LEP vaccine was used significantly more often than for older dogs $(\mathrm{P}<0.05$, data not shown). For both age groups, dogs vaccinated with the Flury LEP vaccine only and dogs vaccinated with the Pasteur RIV vaccine only had a significantly higher risk of failing to reach an antibody level of $0.5 \mathrm{IU} / \mathrm{ml}$ in comparison to dogs vaccinated with the Wistar-G52 vaccine only (Tables 4, 5). Additionally, for both age groups, vaccination with the Flury LEP vaccine only had the highest risk of failing to reach an antibody level of $0.5 \mathrm{IU} / \mathrm{ml}$. In younger dogs, these risks were higher than in older dogs. In younger dogs, if the time between vaccination and sampling was over 3 months, the risk of failing to reach an antibody level of $0.5 \mathrm{IU} / \mathrm{ml}$ was significantly higher than if the time span was shorter. In older dogs, the risk was higher if the time was over 6 months. For older dogs (over 1 year) of a larger size $(>30 \mathrm{~cm})$, the risk of failing to reach an antibody level of $0.5 \mathrm{IU} / \mathrm{ml}$ was greater. In younger dogs, those over $60 \mathrm{~cm}$ had a higher risk compared to smaller dogs.

In cats, we observed no statistically significant differences between the vaccines used (Table 6). However, there was a similar tendency towards a higher risk of failing to reach an antibody level of $0.5 \mathrm{IU} / \mathrm{ml}$ for vaccination with the Flury LEP vaccine only compared to vaccination with the Wistar-G52 vaccine only. Cats that were vaccinated at the age of up to 1 year old had a significantly higher risk of failing to reach an antibody level of $0.5 \mathrm{IU} /$ $\mathrm{ml}$ than cats vaccinated at an older age. Similarly to dogs, cats that were sampled for testing 3-6 months or over 6 months after vaccination had a significantly higher risk of failing to reach an antibody level of $0.5 \mathrm{IU} / \mathrm{ml}$ than cats that had been sampled less than 3 months after vaccination.

\section{Discussion}

New lyssaviruses related to RABV have been discovered, and it is possible that there may still be undetected bat lyssaviruses in many parts of the world. Bats do not often interact with people, but transmission of lyssaviruses to humans and pets has been documented. Finland experienced a human death from EBLV-2 in 1985 [9, $10]$, and better knowledge of the effectiveness of crossprotection is therefore needed to predict the impact of 
Table 2 Descriptive data on samples included in the statistical analysis of dog sera $(n=2681)$ tested for rabies antibody response after vaccination in Finland during 2009-2013

\begin{tabular}{|c|c|c|c|c|c|}
\hline \multirow[t]{2}{*}{ Variable } & \multirow[t]{2}{*}{ Levels } & \multicolumn{2}{|c|}{$\begin{array}{l}\text { Antibody response } \\
<0.5 \mathrm{IU} / \mathrm{ml}(\mathrm{n}=1055)\end{array}$} & \multicolumn{2}{|c|}{$\begin{array}{l}\text { Antibody response } \\
\geq 0.5 \mathrm{IU} / \mathrm{ml}(\mathrm{n}=1626)\end{array}$} \\
\hline & & $\mathbf{n}$ & $\%(95 \% \mathrm{Cl})$ & $\mathbf{n}$ & $\%(95 \% \mathrm{Cl})$ \\
\hline \multicolumn{6}{|l|}{ Age at vaccination (year) } \\
\hline$\leq 1$ & & 544 & $52.2(49.2-55.2)$ & 328 & $20.3(18.4-22.3)$ \\
\hline$>1$ & & 498 & $47.8(44.8-50.8)$ & 1289 & $79.3(77.7-81.6)$ \\
\hline \multicolumn{6}{|l|}{ Gender } \\
\hline Female & & 500 & $54.7(51.5-57.9)$ & 750 & $52.7(50.1-55.3)$ \\
\hline Male & & 414 & $45.3(42.1-48.5)$ & 672 & $47.3(44.7-49.9)$ \\
\hline \multicolumn{6}{|l|}{ Number of vaccinations } \\
\hline Once & & 941 & $89.2(87.2-91.0)$ & 1071 & $65.9(63.5-68.1)$ \\
\hline Twice & & 99 & $9.4(7.7-11.3)$ & 433 & $26.6(24.5-28.8)$ \\
\hline More than twice & & 15 & $1.4(0.8-2.3)$ & 122 & $7.5(6.3-8.9)$ \\
\hline \multicolumn{6}{|c|}{ Time btw vaccination and sampling (months) } \\
\hline$<3$ & & 21 & $2.3(1.5-3.4)$ & 158 & $11.1(9.6-12.9)$ \\
\hline $3-6$ & & 335 & $36.8(33.7-39.9)$ & 459 & $32.3(30.0-34.8)$ \\
\hline$>6$ & & 555 & $60.9(57.7-64.1)$ & 802 & $56.5(53.9-59.1)$ \\
\hline \multicolumn{6}{|l|}{ Vaccine used } \\
\hline Only vaccine Wistar-G52 & & 53 & $7.3(5.6-9.4)$ & 229 & $22.1(19.7-24.7)$ \\
\hline Only vaccine Pasteur RIV & & 298 & $41.3(37.7-44.9)$ & 387 & $37.4(34.5-40.4)$ \\
\hline Only vaccine Flury LEP & & 315 & $43.6(40.0-47.3)$ & 233 & $22.5(20.0-25.1)$ \\
\hline Other & & 56 & $7.8(6.0-9.9)$ & 186 & $18.0(15.7-20.4)$ \\
\hline \multicolumn{6}{|l|}{$\mathrm{FCl}$ group } \\
\hline $\mathrm{FCl1}$ & & 142 & $15.0(12.8-17.4)$ & 186 & $13.4(11.7-15.2)$ \\
\hline $\mathrm{FCl} 2$ & & 114 & $12.1(10.1-14.2)$ & 146 & $10.5(9.0-12.2)$ \\
\hline $\mathrm{FCl} 3$ & & 106 & $11.2(9.3-13.3)$ & 191 & $13.7(12.0-15.6)$ \\
\hline $\mathrm{FCl} 4$ & & 33 & $3.5(2.5-4.8)$ & 47 & $3.4(2.5-4.4)$ \\
\hline $\mathrm{FCl} 5$ & & 138 & $14.6(12.4-16.9)$ & 183 & $13.2(11.5-15.0)$ \\
\hline $\mathrm{FCl} 6$ & & 43 & $4.5(3.4-6.0)$ & 46 & $3.3(2.5-4.3)$ \\
\hline $\mathrm{FCl7}$ & & 75 & $7.9(6.3-9.8)$ & 77 & $5.5(4.4-6.8)$ \\
\hline $\mathrm{FCl} 8$ & & 133 & $14.1(12.0-16.4)$ & 158 & $11.4(9.8-13.1)$ \\
\hline $\mathrm{FCl9}$ & & 109 & $11.5(9.6-13.7)$ & 266 & $19.1(17.1-21.3)$ \\
\hline $\mathrm{FCl10}$ & & 31 & $3.3(2.3-4.6)$ & 36 & $2.6(1.8-3.5)$ \\
\hline No FCl group & & 22 & $2.3(1.5-3.4)$ & 55 & $4.0(3.0-5.1)$ \\
\hline \multicolumn{6}{|l|}{ Breed size $(\mathrm{cm})$} \\
\hline$<30$ & & 178 & $19.2(16.8-21.9)$ & 434 & $32.3(29.9-34.9)$ \\
\hline $30-45$ & & 295 & $31.9(28.9-34.9)$ & 408 & $20.4(28.0-32.9)$ \\
\hline $46-60$ & & 208 & $22.5(19.9-25.2)$ & 267 & $19.9(17.8-22.1)$ \\
\hline$>60$ & & 245 & $26.5(23.7-29.4)$ & 233 & $17.4(15.4-19.5)$ \\
\hline
\end{tabular}

FCl group 1: Sheepdogs and Cattledogs (except Swiss Cattledogs), FCl group 2: Pinscher and Schnauzer-Molossoid and Swiss Mountain and Cattledogs, FCl group 3: Terriers, $\mathrm{FCl}$ group 4: Dachshunds, $\mathrm{FCl}$ group 5: Spitz and primitive types, $\mathrm{FCl}$ group 6: Scent hounds and related breeds, $\mathrm{FCl}$ group 7: Pointing Dogs, $\mathrm{FCl}$ group 8: Retrievers-Flushing Dogs-Water Dogs, FCl group 9: Companion and Toy Dogs, FCl group 10: Sighthounds

$C l$ confidence interval, $n$ number of cases

rabies vaccination if exposed to infected bats, as EBLV-2 appears to be enzootic at least in some areas in Finland $[15,16]$. The immune response elicited by RABV-based rabies vaccines has been shown to be capable of crossprotection against those lyssaviruses in phylogroup I, but not for those that do not belong to this phylogroup
[42-45]. However, even though EBLV-2 belongs to the same phylogroup I as RABV, the protection induced by rabies vaccines has only been limited in an experimental virus challenge study in mice, even with the production of VNAs [34]. 
Table 3 Descriptive data on samples included in the statistical analysis of cat sera $(n=266)$ tested for the rabies antibody response after vaccination in Finland during 2009-2013

\begin{tabular}{|c|c|c|c|c|}
\hline \multirow[t]{2}{*}{ Variable } & \multicolumn{2}{|c|}{$\begin{array}{l}\text { Antibody } \\
\text { response } \\
<0.5 \mathrm{IU} / \mathrm{ml} \\
(\mathrm{n}=25) \\
\end{array}$} & \multicolumn{2}{|c|}{$\begin{array}{l}\text { Antibody response } \\
\geq 0.5 \mathrm{IU} / \mathrm{ml} \\
(\mathrm{n}=241)\end{array}$} \\
\hline & $\mathrm{n}$ & $\%(95 \% \mathrm{Cl})$ & $\mathbf{n}$ & $\%(95 \% \mathrm{Cl})$ \\
\hline \multicolumn{5}{|l|}{ Age at vaccination (year) } \\
\hline$\leq 1$ & 12 & $48.0(29.5-66.9)$ & 47 & $19.6(14.9-25.0)$ \\
\hline$>1$ & 13 & $52.0(33.1-70.5)$ & 193 & $80.4(75.0-85.1)$ \\
\hline \multicolumn{5}{|l|}{ Gender } \\
\hline Female & 5 & $20.0(8.1-38.4)$ & 89 & $58.6(50.6-66.2)$ \\
\hline Male & 8 & $32.0(16.4-51.5)$ & 63 & $26.1(20.9-31.9)$ \\
\hline \multicolumn{5}{|l|}{ Number of vaccinations } \\
\hline Once & 24 & $96.0(82.8-99.6)$ & 194 & $80.5(75.5-85.5)$ \\
\hline Twice & 1 & $4.0(0.4-17.2)$ & 42 & $17.4(13.0-22.6)$ \\
\hline More than twice & 0 & $0.0(0-9.5)$ & 5 & $2.1(0.8-4.5)$ \\
\hline \multicolumn{5}{|c|}{ Time btw vaccination and sampling (months) } \\
\hline$<3$ & 1 & $5.3(0.6-22.1)$ & 78 & $42.2(35.2-49.4)$ \\
\hline $3-6$ & 8 & $42.1(22.3-64.1)$ & 70 & $37.8(31.1-45.0)$ \\
\hline$>6$ & 10 & $52.6(31.2-73.4)$ & 37 & $20.0(14.7-26.2)$ \\
\hline \multicolumn{5}{|l|}{ Vaccine used } \\
\hline Only vaccine Wistar-G52 & 3 & $25.0(7.6-52.9)$ & 39 & $25.7(19.2-33.0)$ \\
\hline Only vaccine Pasteur RIV & 1 & $8.3(0.9-32.8)$ & 63 & $41.4(33.8-49.4)$ \\
\hline Only vaccine Flury LEP & 6 & $50.0(24.3-75.7)$ & 25 & $16.4(11.2-22.9)$ \\
\hline Other & 2 & $16.7(3.6-43.6)$ & 25 & $16.4(11.2-22.9)$ \\
\hline
\end{tabular}

$C /$ confidence interval, $n$ number of cases
VNAs are the main method of protection during rabies infection, and the role of cell-mediated and innate immunity is poorly understood. Measuring the VNA titre is currently the most common way to assess the success of vaccination, and an internationally accepted threshold of $0.5 \mathrm{IU} / \mathrm{ml}$ has therefore been adopted as an adequate titre. In our study, all mice developed a sufficient VNA titre against RABV after vaccination, but mice that had VNA titres of 2-64 IU/ml, which is higher than the accepted threshold, succumbed after challenge with FIEBLV-2 virus, whereas all mice survived the challenge with FIRD-RABV. Due to this discrepancy between the VNA titres and cross-protection from the disease, people and animals need a post-exposure vaccination, regardless of their prior pre-exposure vaccination and antibody measurement result, if they are exposed to lyssaviruses. The intracranial route of infection was used because of the guidelines in the European Pharmacopoeia's protocol. Pharmacopoeial methods are reference methods and the suitability of the method has been demonstrated. However, it should be noted that the intracranial exposure route used in our study is not the natural infection route.

Possible exposure to other lyssaviruses than RABV has especially raised concerns over whether RABV-based vaccines offer sufficient cross-protection and whether a higher cut-off for protection against EBLV-2 would be required. Studies have suggested that either higher serum VNA titres [34] or higher doses of rabies immunoglobulins are required [45] in humans. There is marked individual variation in the comparative neutralisation patterns

Table 4 Multivariable logistic regression results of risk factors for not reaching the antibody level of $0.5 \mathrm{IU} / \mathrm{ml}$ after vaccination against rabies in dogs up to 1 year old $(n=872)$ in Finland during 2009-2013

\begin{tabular}{|c|c|c|c|}
\hline Independent variable & Logistic regression coefficient B & $\begin{array}{l}\text { Wald's } \\
\text { P value }\end{array}$ & Odds ratio $(95 \% \mathrm{Cl})$ \\
\hline \multicolumn{4}{|l|}{ Vaccine } \\
\hline Wistar-G52 only & $\mathrm{Na}$ & $\mathrm{Na}$ & 1 \\
\hline Pasteur RIV only & 2.049 & 0.000 & $7.8(4.1-14.5)$ \\
\hline Flury LEP only & 2.608 & 0.000 & $13.6(7.0-26.2)$ \\
\hline D other & 0.466 & 0.406 & $1.6(0.5-4.8)$ \\
\hline \multicolumn{4}{|l|}{ Breed size $(\mathrm{cm})$} \\
\hline$<30$ & $\mathrm{Na}$ & $\mathrm{Na}$ & 1 \\
\hline $30-60$ & 0.308 & 0.221 & $1.4(0.8-2.2)$ \\
\hline$>60$ & 1.159 & 0.000 & $3.2(1.7-5.9)$ \\
\hline \multicolumn{4}{|c|}{ Time btw vaccination and sampling (months) } \\
\hline$<3$ & $\mathrm{Na}$ & $\mathrm{Na}$ & 1 \\
\hline $3-6$ & 1.400 & 0.001 & $4.1(1.8-9.1)$ \\
\hline$>6$ & 1.508 & 0.000 & $4.5(2.0-10.4)$ \\
\hline Constant & -2.907 & 0.000 & 0.055 \\
\hline
\end{tabular}

$\mathrm{Na}$ not applicable, $\mathrm{Cl}$ confidence interval, other dogs vaccinated abroad with vaccines not available in Finland or with a combination of different vaccines 
Table 5 Multivariable logistic regression results of risk factors for not reaching the antibody level of $0.5 \mathrm{IU} / \mathrm{ml}$ after vaccination against rabies in dogs older than 1 year $(n=1787)$ in Finland during 2009-2013

\begin{tabular}{|c|c|c|c|}
\hline Independent variable & Logistic regression coefficient $B$ & $\begin{array}{l}\text { Wald's } \\
\text { P value }\end{array}$ & Odds ratio $(95 \% \mathrm{Cl})$ \\
\hline \multicolumn{4}{|l|}{ Vaccine } \\
\hline Wistar-G52 only & $\mathrm{Na}$ & $\mathrm{Na}$ & 1 \\
\hline Pasteur RIV only & 0.926 & 0.000 & $2.5(1.5-4.1)$ \\
\hline Flury LEP only & 1.271 & 0.000 & $3.6(2.2-5.9)$ \\
\hline Other & 0.243 & 0.418 & $1.3(0.7-2.3)$ \\
\hline \multicolumn{4}{|l|}{ Breed size $(\mathrm{cm})$} \\
\hline$<30$ & $\mathrm{Na}$ & $\mathrm{Na}$ & 1 \\
\hline $30-60$ & 0.464 & 0.013 & $1.6(1.1-2.3)$ \\
\hline$>60$ & 0.823 & 0.000 & $2.3(1.5-3.5)$ \\
\hline \multicolumn{4}{|c|}{ Time btw vaccination and sampling (months) } \\
\hline$<6$ & $\mathrm{Na}$ & $\mathrm{Na}$ & 1 \\
\hline$>6$ & 1.432 & 0.000 & $4.2(2.8-6.3)$ \\
\hline Constant & -3.180 & 0.000 & 0.042 \\
\hline
\end{tabular}

$\mathrm{Na}$ not applicable, $\mathrm{Cl}$ confidence interval, other dogs vaccinated abroad with vaccines not available in Finland or with a combination of different vaccines

Table 6 Crude and multivariable logistics regression results of risk factors for not reaching the antibody level of 0.5 IU/ $\mathrm{ml}$ after vaccination against rabies in cats in Finland during 2009-2013

\begin{tabular}{|c|c|c|c|}
\hline Independent variable & Logistic regression coefficient $B$ & $\begin{array}{l}\text { Wald's } \\
\text { P value }\end{array}$ & Odds ratio $(95 \% \mathrm{Cl})$ \\
\hline \multicolumn{4}{|c|}{ In crude logistic regressions } \\
\hline \multicolumn{4}{|c|}{ Vaccine $(n=164)$} \\
\hline Wistar-G52 only & $\mathrm{Na}$ & 1 & $\mathrm{Na}$ \\
\hline Pasteur RIV only & -1.578 & 0.178 & $0.2(0.0-2.1)$ \\
\hline Flury LEP only & 1.138 & 0.130 & $3.1(0.7-13.6)$ \\
\hline Other & 0.039 & 0.967 & $1.0(0.2-6.7)$ \\
\hline \multicolumn{4}{|c|}{ Age at vaccination $(n=265)$} \\
\hline$<1$ year vs $\geq 1$ year & 1.332 & 0.002 & $3.8(1.6-8.9)$ \\
\hline \multicolumn{4}{|c|}{ Time btw vaccination and sampling $(n=204)$ (months) } \\
\hline$<3$ & $\mathrm{Na}$ & 1 & $\mathrm{Na}$ \\
\hline $3-6$ & 2.188 & 0.042 & $8.9(1.1-73.1)$ \\
\hline$>6$ & 3.048 & 0.004 & $21.1(2.6-170.9)$ \\
\hline \multicolumn{4}{|c|}{ In multivariable logistic regression $(n=159)$} \\
\hline \multicolumn{4}{|c|}{ Vaccine } \\
\hline Wistar-G52 only & $\mathrm{Na}$ & 1 & $\mathrm{Na}$ \\
\hline Pasteur RIV only & -1.090 & 0.378 & $0.3(0.03-3.8)$ \\
\hline Flury LEP only & 1.475 & 0.085 & $4.4(0.8-23.5)$ \\
\hline Other & 0.827 & 0.439 & $2.3(0.3-16.6)$ \\
\hline \multicolumn{4}{|l|}{ Age at vaccination } \\
\hline$<1$ year $v s \geq 1$ year & 2.282 & 0.006 & $9.8(1.9-48.8)$ \\
\hline \multicolumn{4}{|c|}{ Time btw vaccination and sampling (months) } \\
\hline$<3$ & $\mathrm{Na}$ & 1 & $\mathrm{Na}$ \\
\hline $3-6$ & 1.615 & 0.19 & $5.0(0.5-56.2)$ \\
\hline$>6$ & 2.906 & 0.026 & $18.3(1.4-235.3)$ \\
\hline Constant & -5.439 & 0.000 & 0.004 \\
\hline
\end{tabular}

Na not applicable, $\mathrm{Cl}$ confidence interval, other cats vaccinated abroad with vaccines not available in Finland or with a combination of different vaccines 
of human sera against different lyssaviruses [34, 42]. Our studies indicated that the RABV antibody level does not clearly correlate with protection against EBLV-2. Therefore, laboratory personnel working with EBLV-2 should be regularly vaccinated and their antibody level should be monitored every 6 months, but it is still unclear what RABV antibody level would be protective. Therefore, booster vaccinations are recommended after possible exposure to lyssaviruses, and particular attention should be paid to the wound care after exposure. No laboratory accidents with other lyssaviruses than RABV have so far been reported.

Several factors influence the antibody level reached in an animal after vaccination, including the vaccine used, vaccine administration and the animal receiving the vaccine. Based on our studies, it is advisable that dogs that need a sufficient antibody test result due to international travel should be vaccinated twice with a rabies vaccine and then regularly receive a booster. Sihvonen et al. [40] demonstrated that a single vaccination of dogs with rabies vaccine induced moderate but short-term seroconversion in $96.9 \%$ of dogs, but in $17 \%$ of dogs the antibody titre did not last for a whole year in a population that had not previously been vaccinated. If vaccinations are only performed by veterinarians in veterinary clinics and vaccines are stored according to the manufacturer's instructions, this might have a positive effect on the outcome. Factors such as the consistency (virus strain, cell culture and adjuvants) of the vaccine influence the vaccination response.

The difference between the proportions of dogs (around 11\%) and cats (around 3\%) that failed to reach the antibody level of $0.5 \mathrm{IU} / \mathrm{ml}$ might be caused by differences in genetic variation within the two species, as pedigree dogs are purebred, whereas the majority of cats in our study material were mixed breeds. The key genetic elements of immune responsiveness lie within the genes of the major histocompatibility complex (MHC). It has been suspected that cats have more limited diversity in immune response genes than dogs, but recent research has demonstrated similar variation in the MHC in cats to that found in dogs [51]. In our study, there was a significant difference in the ability of different vaccines to induce the antibody level of $0.5 \mathrm{IU} / \mathrm{ml}$ in dogs. This has also been reported in earlier studies [36-39], and may be due to differences in the immunogenicity of the vaccines or the potency of the vaccine batches. Moreover, veterinarians should note that there are significant differences between vaccines in their ability to induce an immune response. This difference between the vaccines was not statistically significant in cats, perhaps due to the type two error of an insufficient sample size, since there were so few $(n=25)$ failures to reach the threshold of $0.5 \mathrm{IU} /$ $\mathrm{ml}$ in cats.

The time between vaccination and sampling was a significant risk factor for both dogs and cats failing to reach the threshold of $0.5 \mathrm{IU} / \mathrm{ml}$. The antibody level peaks at slightly different times after vaccination with different vaccines, and the level starts to decline afterwards [37]. Larger dogs had a greater risk of failing to reach the required antibody level. Increasing the dose would not probably be a solution, since it has been shown that if there is a sufficient antigen to create a response, larger doses will not increase antibody production. Kennedy et al. [37] suggested that larger breeds might have deeper sub-cutaneous fat, which could reduce the level of the antibody response. The breed might also be a factor, not just the size of the dog, since even though most failures to reach the anticipated antibody level occurred in larger breeds, some smaller breeds had significant test failure rates [52]. Specific dog breeds have a genetically determined immune function, and a study has confirmed breed-specific serological response patterns to vaccination. The high interbreed and relatively low intrabreed variation in MHC alleles and haplotypes could provide an explanation for the reports of interbreed variation in immune responses to vaccines [53]. The higher risk of failing to reach $0.5 \mathrm{IU} / \mathrm{ml}$ for dogs and cats aged up to 1 year old could be due to the administration of vaccines before the animals had reached full immunocompetency, or due to maternal antibodies [36, 39].

In rabies-free countries, the rabies vaccination coverage of cats and dogs is likely to be lower than in rabies enzootic countries. Cats, especially in the countryside, often freely roam outside and are therefore able to encounter wildlife, consequently being at greater risk of exposure to rabid animals, and especially to bats, than dogs. Host switching of lyssaviruses from bats to mammals has successfully occurred in history [20,21]. Natural spillover of EBLV-2 to other mammals than humans has not been demonstrated. Only a small proportion of cats failed to reach the required antibody level in our study, but the vaccination coverage of cats against rabies is assumed to be low in many rabies-free countries, at least in Finland. Based on the number of vaccination doses sold, we estimated that about $10-20 \%$ of 700,000 Finnish cats have been vaccinated against rabies. The rabies vaccination coverage is higher for dogs, estimated at around 40-65\% based on the rabies vaccine sales in Finland.

We demonstrated in the mouse model challenge that an RABV-based animal vaccine offers cross-protection against challenge with the FI-EBLV-2 strain isolated from a bat. Therefore, it is recommended that even in rabiesfree countries, dogs and cats that come into contact with lyssavirus and infected bats should be vaccinated against 
rabies. Booster vaccination is recommended for dogs, especially of large breeds. Moreover, veterinarians should pay attention to the choice of vaccine used.

\section{Conclusions}

A veterinary RABV-based rabies vaccine, selected based on the ability to induce the best antibody response of the vaccines compared for dogs and cats in this study, offered cross-protection against EBLV-2 challenge in a mouse model in comparison with a challenge with RABV. Our mouse model provided an indication that the RABV antibody level and protection against EBLV-2 are not clearly correlated, and this most probably reflects the situation in other mammals and humans. There was a statistically significant difference in VNA titres between three groups of mice vaccinated with different vaccines or vaccination schemes. Approximately $11 \%$ of vaccinated dogs tested from the field failed to have an antibody titre of $0.5 \mathrm{IU} /$ $\mathrm{ml}$ or more. By comparison, only a small proportion of cats failed to reach the required antibody level. Booster vaccination and vaccinating dogs and cats encountering bats is recommended, since vaccination also offers crossprotection against EBLV-2.

\section{Authors' contributions}

TN participated in the study design, conducted the challenge experiment, performed the serological and virological analysis and drafted the manuscript. MJV and LS participated in the study design and critically revised the draft for important intellectual content. AMV supervised the statistical analysis and critically revised the draft for important intellectual content. All authors read and approved the final manuscript.

\section{Author details}

${ }^{1}$ Finnish Food Safety Authority Evira, Mustialankatu 3, 00790 Helsinki, Finland. ${ }^{2}$ Department of Veterinary Biosciences, Faculty of Veterinary Medicine, University of Helsinki, P.O. Box 66, 00014 Helsinki, Finland.

\section{Acknowledgements}

Thanks to Raili Heinonen, Sanna Karumaa and Tiina Peltonen, and other technicians at Evira, for their technical assistance. Thanks to Veera Karkamo, DVM, for the autopsies of mice.

\section{Competing interests}

The authors declare that they have no competing interests.

\section{Availability of data and materials}

The datasets used and/or analysed during the current study are available from the corresponding author on reasonable request.

\section{Consent for publication}

Not applicable.

\section{Ethics approval and consent to participate}

The National Animal Experiment Board of the County Administrative Board of Southern Finland approved the diagnostic mouse inoculation test (permission number ESLH-2008-06899/ /m-23). The vaccination and intracerebral inoculation challenge was carried out with the permission of the National Animal Experiment Board of the County Administrative Board of Southern Finland (permission number ESAVI-2010-06673/Ym-23 and ESAVI/955/04.10.07/2013), which followed the Finnish Act on the Use of Animals for Experimental Purposes (62/2006).
Funding

This study was funded by the Ministry of Agriculture and Forestry (Grant MMM 2682/311/2009) and the Finnish Food Safety Authority Evira.

\section{Publisher's Note}

Springer Nature remains neutral with regard to jurisdictional claims in published maps and institutional affiliations.

Received: 21 April 2017 Accepted: 24 September 2017

Published online: 02 October 2017

References

1. WHO expert consultation on rabies 2013. http://apps.who.int/iris/bitstr eam/10665/85346/1/9789240690943_eng.pdf. Accessed 12 Nov 2016.

2. Badrane $H$, Bahloul C, Perrin P, Tordo N. Evidence of two lyssavirus phylogroups with distinct pathogenicity and immunogenicity. J Virol. 2001;75:3268-76.

3. Kuzmin IV, Mayer AE, Niezgoda M, Markotter W, Agwanda B, Breiman RF, et al. Shimoni bat virus, a new representative of the Lyssavirus genus. Virus Res. 2010;149:197-210.

4. Kuzmin IV, Hughes GJ, Botvinkin AD, Orciari LA. Rupprecht CE phylogenetic relationships of Irkut and West Caucasian bat viruses within the Lyssavirus genus and suggested quantitative criteria based on the $\mathrm{N}$ gene sequence for lyssavirus genotype definition. Virus Res. 2005;111:28-43.

5. Marston DA, Horton DL, Ngeleja C, Hampson K, McElhinney LM, Banyard AC, et al. Ikoma lyssavirus, highly divergent novel lyssavirus in an African civet. Emerg Infect Dis. 2012;18:664-7.

6. Ceballos NA, Morón SV, Berciano JM, Nicolás O, López CA, Juste J, et al. Novel lyssavirus in bat, Spain. Emerg Infect Dis. 2013;19:793-5.

7. Gunawardena P, Marston D, Ellis R, Wise E, Karawita A, Breed A, et al. Lyssavirus in Indian flying foxes, Sri Lanka. Emerg Infect Dis. 2016;22:1456-8.

8. Johnson N, Vos A, Freuling C, Tordo N, Fooks AR, Müller T. Human rabies due to lyssavirus infection of bat origin. Vet Microbiol. 2010;142:151-9.

9. Lumio J, Hillbom M, Roine R, Ketonen L, Haltia M, Valle M, et al. Human rabies of bat origin in Europe. Lancet. 1986;15:378.

10. Roine RO, Hillbom M, Valle M, Haltia M, Ketonen L, Neuvonen E, et al. Fatal encephalitis caused by a bat-borne rabies-related virus: clinical findings. Brain. 1988;111:1505-16.

11. Fooks AR, McElhinney LM, Pounder DJ, Finnegan CJ, Mansfield K, Johnson $\mathrm{N}$, et al. Case report: isolation of a European bat lyssavirus type $2 \mathrm{a}$ from a fatal human case of rabies encephalitis. J Med Virol. 2003;71:281-9.

12. Van der Poel WHM, Van der Heide R, Verstraten E, Takumi K, Lina PHC, Kramps JA. European bat lyssaviruses, the Netherlands. Emerg Infect Dis. 2005;11:1854-9.

13. Kappeler A. First case of rabies in a bat in Switzerland. Rabies Bull Eur. 2002;16:11.

14. Whitby JE, Heaton PR, Black EM, Wooldridge M, McElhinney LM, Johnstone P. First isolation of a rabies-related virus from a Daubenton's bat in the United Kingdom. Vet Rec. 2000;147:385-8.

15. Jakava-Viljanen M, Lilley T, Kyheröinen E-M, Huovilainen A. First encounter of European bat lyssavirus type 2 (EBLV-2) in a bat in Finland. Epidemiol Infect. 2010;138:1581-5.

16. Nokireki T, Huovilainen A, Lilley T, Kyheröinen EM, Ek-Kommonen C, Sihvonen L, Jakava-Viljanen M. Bat rabies surveillance in Finland. BMC Vet Res. 2013;9:174.

17. Freuling C, Grossmann E, Conraths FJ, Schameitat A, Kliemt J, Auer E, et al. First isolation of EBLV-2 in Germany. Vet Microbiol. 2008;131:26-34.

18. Rasmussen TB, Chriél M, Baagøe HJ, Fjederholt E, Kooi EA, Belsham GJ, Bøtner A. Detection of European bat lyssavirus type 2 in Danish Daubenton's bats using a molecular diagnostic strategy. In: Proceedings of 8th Annual EPIZONE Meeting, 23-25.9.2014, Copenhagen, Denmark.

19. Moldal T, Vikøren T, Cliquet F, Marston DA, van der Kooij J, Madslien K, Ørpetveit I. First detection of European bat lyssavirus type 2 (EBLV-2) in Norway. BMC Vet Res. 2017;13:216.

20. Leslie MJ, Messenger S, Rohde RE, Smith J, Cheshier R, Hanlon C, Rupprecht CE. Bat-associated rabies virus in skunks. Emerg Infect Dis. 2006;12:1274-7. 
21. Daoust PY, Wandeler Al, Casey GA. Cluster of rabies cases of probable bat origin among red foxes in Prince Edward Island, Canada. J Wildl Dis. 1996;32:403-6.

22. Cliquet F, Picard-Meyer E, Barrat J, Brookes SM, Healy DM, Wasniewski M, Litaize E, Biarnais M, Johnson L, Fooks AR. Experimental infection of foxes with European bat lyssaviruses type-1 and 2. BMC Vet Res. 2009;5:19.

23. Brookes SM, Klopfleisch R, Müller T, Healy DM, Teifke JP, Lange E, Kliemt J, Johnson N, Johnson L, Kaden V, Vos A, Fooks AR. Susceptibility of sheep to European bat lyssavirus type-1 and -2 infection: a clinical pathogenesis study. Vet Microbiol. 2007;125:210-23.

24. Banyard AC, Healy DM, Brookes SM, Voller K, Hicks DJ, Núñez A, Fooks AR. Lyssavirus infection: 'Iow dose, multiple exposure' in the mouse model. Virus Res. 2014;181:35-42.

25. Healy DM, Brookes SM, Banyard AC, Núñez A, Cosby SL, Fooks AR. Pathobiology of rabies virus and the European bat lyssaviruses in experimentally infected mice. Virus Res. 2013;172:46-53.

26. Müller T, Cox J, Schafer R, Johnson N, McElhinney LM, Geue JL, Tjørnehøj K, Fooks AR. Spill-over of European bat lyssavirus type 1 into a stone marten (Martes foina) in Germany. J Vet Med B Infect Dis Vet Public Health. 2004:51:49-54.

27. Tjørnehøj K, Fooks AR, Agerholm JS, Rønsholt L. Natural and experimental infection of sheep with European bat lyssavirus type-1 of Danish bat origin. J Comp Pathol. 2006;134:190-201.

28. Tjørnehøj K, Rønsholt L, Fooks AR. Antibodies to EBLV-1 in a domestic cat in Denmark. Vet Rec. 2004;155:571-2.

29. European Pharmacopoeia 6.0. (2008). Monograph 0451: Rabies vaccine (inactivated) for veterinary use. European Directorate for the quality of medicines and healthcare [EDQM], Council of Europe, Strasbourg, France.

30. OIE manual of diagnostic tests and vaccines for terrestrial animals 2015. http://www.oie.int/en/international-standard-setting/terrestrial-manual/ access-online/. Accessed 12 Nov 2016.

31. Moore SM, Wilkerson MJ, Davis RD, Wyatt CR, Briggs DJ. Detection of cellular immunity to rabies antigens in human vaccines. J Clin Immunol. 2006;26:533-45

32. Aubert MF. Practical significance of rabies antibodies in cats and dogs. Rev Sci Tech. 1992;3:735-60.

33. Hooper DC, Morimoto K, Bette M, Weihe E, Koprowski H, Dietzschold B. Collaboration of antibody and inflammation in clearance of rabies virus from the central nervous system. J Virol. 1998;72:3711-9.

34. Brookes SM, Parsons G, Johnson N, McElhinney LM, Fooks AR. Rabies human diploid cell vaccine elicits cross-neutralising and cross-protecting immune responses against European and Australian bat lyssaviruses. Vaccine. 2005;23:4101-9.

35. Malerczyk C, Selhorst T, Tordo N, Moore S, Müller T. Antibodies induced by vaccination with purified chick embryo cell culture vaccine (PCECV) cross-neutralize non-classical bat lyssavirus strains. Vaccine. 2009;27:5320-5.

36. Mansfield KL, Burr PD, Snodgrass DR, Sayers R, Fooks AR. Factors affecting the serological response of dogs and cats to rabies vaccination. Vet Rec. 2004;154:423-6.

37. Kennedy LJ, Lunt M, Barnes A, McElhinney L, Fooks AR, Baxter DN, et al. Factors influencing the antibody response of dogs vaccinated against rabies. Vaccine. 2007:25:8500-7.
38. Minke JM, Bouvet J, Cliquet F, Wasniewski M, Guiot AL, Lemaitre L, et al. Comparison of antibody responses after vaccination with two inactivated rabies vaccines. Vet Microbiol. 2008;133:283-6.

39. Berndtsson LT, Nyman A-K, Rivera E, Klingeborn B. Factors associated with the success of rabies vaccination of dogs in Sweden. Acta Vet Scand. 2011;53:22

40. Sihvonen L, Kulonen K, Neuvonen E, Pekkanen K. Rabies antibody in vaccinated dogs. Acta Vet Scand. 1995;36:87-91.

41. Klevar S, Høgåsen HR, Davidson RK, Hamnes IS, Berndtsson LT, Lund A. Cross-border transport of rescue dogs may spread rabies in Europe. Vet Rec. 2015:176:672.

42. Horton DL, McElhinney LM, Marston DA, Wood JL, Russell CA, Lewis N, Kuzmin IV, Fouchier RA, Osterhaus AD, Fooks AR, Smith DJ. Quantifying antigenic relationships among the lyssaviruses. J Virol. 2010;84:11841-8.

43. Malerczyk C, Freuling C, Gniel D, Giesen A, Selhorst T, Müller T. Crossneutralization of antibodies induced by vaccination with purified chick embryo cell vaccine (PCECV) against different Lyssavirus species. Hum Vaccin Immunother. 2014;10:2799-804.

44. Hanlon CA, Kuzmin IV, Blanton JD, Weldon WC, Manangan JS, Rupprecht CE. Efficacy of rabies biologics against new lyssaviruses from Eurasia. Virus Res. 2005;111:44-54.

45. Liu Y, Chen Q, Zhang F, Zhang S, Li N, Lian H, Wang Y, Zhang J, Hu R. Evaluation of rabies biologics against Irkut virus isolated in China. J Clin Microbiol. 2013;51:3499-504.

46. Fekadu M, Shaddock JH, Sanderlin DW, Smith JS. Efficacy of rabies vaccines against Duvenhage virus isolated from European house bats (Eptesicus serotinus), classic rabies and rabies-related viruses. Vaccine. 1988;6:533-9.

47. Koprowski H. The mouse inoculation test in: laboratory techniques in rabies. 4th ed. Geneva: World Health Organization; 1996.

48. Cliquet F, Aubert MFA, Sagné L. Development of a fluorescent antibody virus neutralizing test (FAVN test) for the quantitation of rabies-neutralising antibody. J Immunol Methods. 1998;212:79-87.

49. Brown L, Cai T, DasGupta A. Interval estimation for a binominal proportion. Stat Sci. 2001;16:101-33.

50. Sergeant ESG. Epitools epidemiological calculators. AusVet Animal Health Services and Australian Biosecurity Cooperative Research Centre for Emerging Infectious Disease. 2015. http://epitools.ausvet.com.au/ content.php?page=home. Accessed 22 Apr 2015.

51. Day MJ. Immune system development in the dog and cat. J Comp Pathol. 2007;137(Suppl 1):S10-5.

52. Kennedy LJ, Lunt M, Barnes A, McElhinney LM, Fooks AR, Ollier WER. Do dogs vary in their response to rabies vaccination?. In: Proceedings of the 48th annual congress of the british small animal veterinary association. 2005. p. 550.

53. Kennedy LJ, Barnes A, Happ GM, Quinnell RJ, Bennett D, Angles JM, Day MJ, Carmichael N, Innes JF, Isherwood D, Carter SD, Thomson W, Ollier WE. Extensive interbreed, but minimal intrabreed, variation of DLA class II alleles and haplotypes in dogs. Tissue Antigens. 2002;59:194-204.

\section{Submit your next manuscript to BioMed Central and we will help you at every step:}

- We accept pre-submission inquiries

- Our selector tool helps you to find the most relevant journal

- We provide round the clock customer support

- Convenient online submission

- Thorough peer review

- Inclusion in PubMed and all major indexing services

- Maximum visibility for your research

Submit your manuscript at www.biomedcentral com/submit 